\title{
IMPLEMENTASI KAJIAN KELAYAKAN FINANSIAL UNTUK MENINGKATKAN TINGKAT KEMATANGAN MANAJEMEN INVESTASI TEKNOLOGI INFORMASI
}

\author{
Benny Ranti ${ }^{1}$ dan Johan Tambotoh ${ }^{2}$ \\ ${ }^{1}$ Fakultas Ilmu Komputer, Universitas Indonesia, Kampus Baru UI Depok, Jawa Barat, 16424, Indonesia \\ ${ }^{2}$ Program Studi Sistem Informasi, Fakultas Teknologi Informasi, Universitas Kristen Satya Wacana, J1. \\ Diponegoro 52-60, Salatiga, 50711, Indonesia \\ E-mail: benny.ranti@infosolusi.co.id
}

\begin{abstract}
Abstrak
Salah satu pilar utama atau domain dari pengelolaan teknologi informasi (TI) adalah investasi TI. Oleh karena itu, strategi untuk mengelola investasi TI sangat penting untuk mendukung keberhasilan pelaksanaan pengelolaan TI (IT Governance). Perusahaan perlu mengetahui tingkat kematangan dari manajemen investasi TI yang dapat membantu mengelola investasi TI dengan benar. Penelitian ini melakukan pengukuran terhadap peningkatan level kematangan manajemen investasi TI pada perusahaan BUMN setelah mengaplikasikan studi kelayakan finansial berdasarkan Generic IS/IT Business Values oleh Ranti, pada setiap tahap investasi TI serta meningkatkan struktur organisasi TI dengan membentuk IT steering committee. Hasil dari penelitian ini menunjukkan bahwa level kematangan manajemen investasi TI meningkat dari level 1 menjadi level 3.
\end{abstract}

Kata Kunci: tingkat investasi TI, IT governance, generic IS/IT business values

\begin{abstract}
One of the key pillars or domains of Information Technology (IT) Governance is IT investment. Therefore, the strategy to manage IT investment is essential to support the successful implementation of IT Governance. Companies need to know the maturity level of IT investment management that can help them managing the IT investment properly. This research measures the increase of IT investment management maturity level of a state-owned company in Indonesia (BUMN) after applying the Financial Feasibility Study based on Ranti's Generic IS/IT Business Values in each IT investment stage as well as improving IT organization structure by forming IT Steering Committee. The result of this study indicates that the level of IT investment management maturity has increased from level 1 to level 3 .
\end{abstract}

Keywords: level of IT investment, IT governance, generic IS / IT business values

\section{Pendahuluan}

Teknologi Informasi (TI) memiliki peran strategis dalam proses bisnis yang dapat dilihat dari keselarasan antara strategi bisnis dan TI. Keselarasan ini dapat diukur melalui kemampuan organisasi atau perusahaan untuk mendapatkan manfaat atau nilai dari investasi TI yang dilakukan. Manfaat tersebut berupa peningkatan kinerja bisnis, peningkatan produktivitas, menciptakan efisiensi, meningkatkan pangsa pasar, menciptakan inovasi layanan dan produk baru bagi pelanggan, dan meningkatkan kemampuan perusahaan untuk mengintegrasikan proses bisnis dalam perusahaan [1].

Untuk memastikan bahwa investasi TI menghasilkan manfaat seperti yang diharapkan, maka perusahaan harus memberikan perhatian pada manajemen investasi TI [2]. Ada empat hal penting yang perlu dijawab terkait dengan manajemen investasi TI, yaitu: (1) Apakah kita melakukan hal yang benar?, (2) Apakah kita melakukannya dengan benar?, (3) Apakah kita memastikan hal itu dilakukan dengan baik?, dan (4) Apakah kita mendapatkan manfaat? [3]. Jawaban dari pertanyaan di atas akan digunakan sebagai acuan dalam membangun tahapan proses investasi TI yang terintegrasi melalui kegiatan praseleksi atau identifikasi kebutuhan, seleksi, pengendalian, dan evaluasi.

Salah satu cara untuk mengetahui keberhasilan manajemen investasi TI adalah dengan mengukur tingkat kematangan manajemen investasi TI. Information Technology Investment Management (ITIM) yang dikembangkan oleh The United States Government Accountability Office (US GAO) adalah suatu kerangka untuk mengukur tingkat kematangan manajemen 
investasi TI dan menentukan perbaikan yang diperlukan [4]. Perbaikan yang dilakukan terkait dengan upaya untuk meningkatkan tingkat kematangan manajemen investasi TI.

Pemanfaatan Kajian Kelayakan Finansial (KKF) dalam proses manajemen investasi TI dapat meningkatkan tingkat kematangan secara signifikan. KKF TI pada dasarnya merupakan analisis biaya-manfaat. Dikarenakan perhitungan biaya lebih mudah dibandingkan pengukuran manfaat TI, maka dalam tulisan ini, KKF difokuskan pada nilai atau manfaat bisnis TI. Salah satu metode yang mendukung KKF adalah Ranti's Generic IS/IT Business Values [5] yang dikembangkan untuk memudahkan proses identifikasi manfaat bisnis TI.

Tulisan ini mendiskusikan pemanfaatan KKF berdasarkan Ranti's Generic IS/IT Business Value pada setiap tahapan manajemen investasi TI untuk meningkatkan kematangan manajemen investasi TI pada perusahaan. Sebagai studi kasus, maka pemanfaatan $\mathrm{KKF}$ untuk meningkatkan tingkat kematangan manajemen investasi TI ini dilakukan pada salah satu Badan Usaha Milik Negara (BUMN).

Seluruh informasi terkait BUMN didapatkan dari sumber-sumber internal yang tidak dipublikasikan. BUMN ini merupakan salah satu BUMN terbesar di Indonesia yang membelanjakan rata-rata lebih dari 20 juta USD per tahun untuk belanja modal dan operasional TI. Dana tersebut berasal dari sumber internal perusahaan maupun eksternal, misalnya pinjaman dan hibah dari negara donor. Besarnya investasi TI tersebut membutuhkan perhatian penting dari manajemen puncak perusahaan manapun, terutama bagi BUMN ini. Investasi TI diharapkan dapat menghasilkan manfaat yang ekonomis, tidak hanya bagi perusahaan tetapi juga bagi pemerintah Indonesia sebagai pemegang saham utama pada BUMN.

BUMN ini telah menetapkan KKF dan Kajian Kelayakan Operasional (KKO) sebagai kebijakan perusahaan serta menjadi syarat untuk semua proyek yang akan dijalankan. Masalahnya adalah bagaimana menyusun KKF yang komprehensif dan terstruktur untuk memudahkan pengusulan proyek, pengelolaan proyek oleh manajer, persetujuan pimpinan, dan pemeriksaan oleh auditor yang akan melakukan post-audit. Semua pihak yang terlibat dalam menyiapkan, melaksanakan, dan mengendalikan investasi TI diharapkan memiliki metode yang sama untuk meningkatkan efektivitas dalam pengelolaan investasi TI di BUMN.
Tata kelola TI merupakan bagian dari Good Corporate Governance (GCG). Menurut Grembergen [2], fokus utama tata kelola TI adalah bagaimana organisasi melaksanakan, mengelola, dan mengoptimalkan sumber daya TI dalam mendukung tujuan perusahaan. Weill dan Ross [6] mengusulkan lima pilar utama atau domain dari Tata kelola TI yaitu: (1) Prinsip TI yang merupakan pernyataan tingkat tinggi tentang bagaimana TI digunakan dalam bisnis, (2) Arsitektur TI, (3) Infrastruktur TI, (4) Kebutuhan aplikasi bisnis, dan (5) Prioritisasi dan investasi TI yang merupakan keputusan tentang berapa banyak dan di mana investasi TI akan dilakukan, termasuk persetujuan dan teknik justifikasi investasi TI. Information Technology Governance Institute (ITGI) [3] merekomendasikan lima domain utama tata kelola TI, yaitu keselarasan strategis, pengukuran kinerja, pengelolaan sumber daya, manajemen risiko, dan penyampaian nilai penciptaan nilai yang berkaitan dengan penciptaan nilai .

Baik Weill dan Ross, maupun ITGI menekankan pentingnya justifikasi investasi TI. Hal ini sejalan dengan hasil penelitian yang dilakukan oleh Grembergen [7]. Pada tahun 2009, Grembergen melakukan survei terhadap manajer bisnis dan TI senior pada 22 perusahaan keuangan di Eropa yang memiliki tingkat penggunaan TI yang cukup tinggi. Penelitian ini mengidentifikasi 33 mekanisme tata kelola TI yang berkaitan dengan keselarasan antara strategi bisnis dan TI. Hasil akhir menunjukkan bahwa kebutuhan Komite Pengarah TI untuk mengevaluasi dan memprioritaskan investasi TI merupakan prioritas utama bagi responden. Prioritas ke-2 dan ke-3 adalah hal-hal yang berkaitan dengan manajemen investasi TI termasuk KKF yang meliputi business case, information economics, Return on Investment, dan payback.

Tingkat kematangan manajemen investasi TI dapat diukur dengan kerangka atau metode ITIM. Menurut ITIM, siklus hidup proses investasi TI terdiri dari 3 tahap, yaitu: (a) Tahap seleksi untuk menentukan proyek yang akan didanai, (b) Tahap pengendalian untuk memastikan dan mengontrol proses investasi TI, dan (c) Tahap evaluasi untuk mengevaluasi apakah investasi TI memenuhi harapan atau tidak. Kerangka ITIM terdiri dari lima tingkat kematangan, 14 proses penting, dan 93 praktek kunci yang tersebar pada setiap tingkat kematangan manajemen investasi TI, seperti yang ditunjukkan pada gambar 1 . 
TINGKAT KEMATANGAN

\begin{tabular}{|c|c|}
\hline $\begin{array}{l}\text { Tahap } 5 \\
\text { Memanfaatkan TI untuk } \\
\text { manfaat strategis }\end{array}$ & $\begin{array}{l}\text { - Mengoptimalisasi proses investasi TI } \\
\text { - Menggunakan TI untuk menggerakkan } \\
\text { perubahan strategi bisnis }\end{array}$ \\
\hline $\begin{array}{l}\text { Tahap } 4 \\
\text { Meningkatkan proses } \\
\text { investasi TI }\end{array}$ & $\begin{array}{l}\text { - Meningkatkan kinerja portofolio investasi TI } \\
\text { - Mengelola suksesi sistem informasi }\end{array}$ \\
\hline $\begin{array}{l}\text { Tahap 3 } \\
\text { Membangun portofolio } \\
\text { investasi TI yang lengkap }\end{array}$ & $\begin{array}{l}\text { - Mendefinisikan kriteria portofolio investasi TI } \\
\text { - } \quad \text { Menciptakan portofolio investasi TI } \\
\text { - } \quad \text { Melakukan tinjauan paska-implementasi }\end{array}$ \\
\hline $\begin{array}{l}\text { Tahap 2 } \\
\begin{array}{c}\text { Membangun dasar/fondasi } \\
\text { investasi TI }\end{array}\end{array}$ & $\begin{array}{l}\text { - Melembagakan dewan/komite pengarah investasi TI } \\
\text { - Memenuhi kebutuhan bisnis } \\
\text { - Memilih investasi } \\
\text { - Menediakan pengawasan investasi } \\
\end{array}$ \\
\hline $\begin{array}{l}\text { Tahap 1 } \\
\text { Menciptakan kesadaran } \\
\text { terhadap investasi TI }\end{array}$ & $\begin{array}{l}\text { - Belanja TI tanpa kedisiplinan proses investasi TI } \\
(\text { Ad Hoc })\end{array}$ \\
\hline
\end{tabular}

Gambar 1. Tingkat kematangan dan proses kritikal pada kerangka ITIM

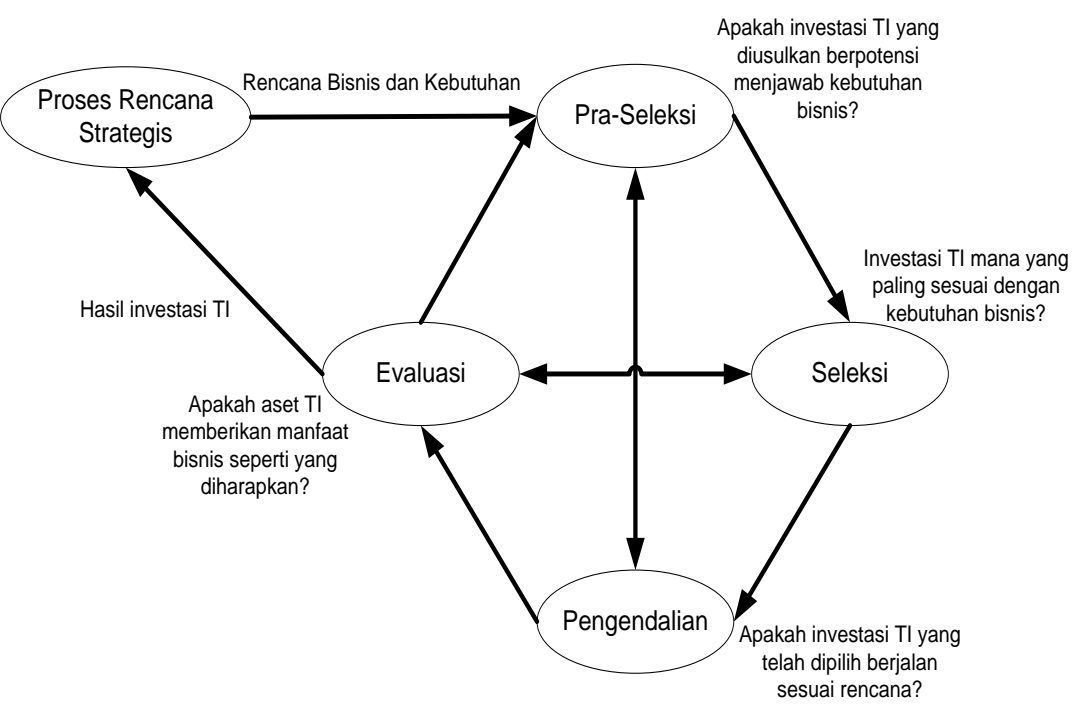

Gambar 2. Proses manajemen investasi TI menurut Over.

Setiap proses penting memiliki praktik kunci yang merupakan indikator tingkat kematangan manajemen investasi TI. Praktek kunci meliputi: (a) Komitmen organisasi, untuk memastikan pihak manajemen bahwa proses penting dilaksanakan; (b) Prasyarat, untuk menjamin bahwa pelaksanaan proses kritikal berjalan baik; dan (c) Kegiatan yang mendukung pelaksanaan proses kritikal.

Over [8] mengembangkan model manajemen investasi TI dengan menambahkan satu tahap ke dalam tahapan ITIM, yaitu tahap praseleksi untuk mengidentifikasi keselarasan antara rencana investasi TI dengan strategi bisnis seperti yang ditunjukkan pada gambar 2 .
Kajian kelayakan finansial dilakukan setelah mengidentifikasi kebutuhan pengguna dan digunakan pada keseluruhan siklus proyek TI [9]. Dennis [10] membagi kajian kelayakan menjadi: (a) Kajian Kelayakan Operasional (KKO) yang mengukur bagaimana TI digunakan dan dioperasikan pada perusahaan, (b) Kajian Kelayakan Teknis (KKT) yang mengukur kepraktisan teknik dan solusi teknologi yang ditawarkan, dan (c) Kajian Kelayakan Finansial (KKF) yang mengukur dampak ekonomis dari proyek dan investasi TI. KKF merupakan fokus dari tulisan ini. Seperti dijelaskan sebelumnya, KKF yang dimaksud dalam tulisan ini adalah KKF berdasarkan Ranti's Generic IS/IT Business Value. 
TABEL I

RANTI'S GENERIC IS/IT BUSINESS VALUE

\begin{tabular}{|c|c|}
\hline Categories & Sub-categories \\
\hline 1. Reducing Cost & $\begin{array}{l}\text { 1. Telecommunications cost } \\
\text { 2. Travelling cost } \\
\text { 3. Staff/operator/employee cost } \\
\text { 4. Meeting cost } \\
\text { 5. Service failure cost } \\
\text { 6. Delivery cost } \\
\text { 7. Training cost per employee } \\
\text { 8. Returning cost for incorrect delivery } \\
\text { 9. Cost of money } \\
\text { 10. Office supplies and printing cost } \\
\text { 11. Subscription cost } \\
\text { 12. Space rental cost } \\
\text { 13. Device rental cost } \\
\text { 14. Inventory cost } \\
\text { 15. Research failure cost }\end{array}$ \\
\hline 2. Increasing & 16. Restructuring job function \\
\hline Productivity & $\begin{array}{l}\text { 17. Acelerating mastering product knowledge } \\
\text { 18. Ease of analysis } \\
\text { 19. Increasing employee satisfaction }\end{array}$ \\
\hline 3. Accelerating & 20. Production process \\
\hline Process & $\begin{array}{l}\text { 21. Stock procurement process } \\
\text { 22. Report making process } \\
\text { 23. Data preparation process } \\
\text { 24. Request/Order checking process } \\
\text { 25. Debt payment process } \\
\text { 26. Transaction process } \\
\text { 27. Decision making process }\end{array}$ \\
\hline 4. Reducing Risk & $\begin{array}{l}\text { 28. Price miscalculation } \\
\text { 29. Unrecoverable claim } \\
\text { 30. Inventory lost } \\
\text { 31. Rejected goods } \\
\text { 32. Data lost } \\
\text { 33. Incorrect data } \\
\text { 34. Penalty } \\
\text { 35. Losing potential employee } \\
\text { 36. Forgery } \\
\text { 37. Administration fraud } \\
\text { 38. Incorrect payment } \\
\text { 39. Asset mismanagement }\end{array}$ \\
\hline $\begin{array}{l}\text { 5. Increasing } \\
\text { Revenue }\end{array}$ & $\begin{array}{l}\text { 40. Increasing business capacity } \\
\text { 41. Increasing report quality } \\
\text { 42. Increasing customer trust } \\
\text { 43. Widening market segment } \\
\text { 44. Increasing other incomes }\end{array}$ \\
\hline $\begin{array}{l}\text { 6. Increasing } \\
\text { Accuracy }\end{array}$ & $\begin{array}{l}\text { 45. Billing } \\
\text { 46. Analysis } \\
\text { 47. Data } \\
\text { 48. Planning } \\
\text { 49. Decision }\end{array}$ \\
\hline $\begin{array}{l}\text { 7. Accelerating } \\
\text { Cash-in }\end{array}$ & 50. Accelerating billing dispatching \\
\hline $\begin{array}{l}\text { 8. Increasing } \\
\text { External Services }\end{array}$ & $\begin{array}{l}\text { 51. Reducing order cancellation } \\
\text { 52. Knowing customer's problems } \\
\text { 53. Adding point of services } \\
\text { 54. Personalized services } \\
\text { 55. Customer satisfaction }\end{array}$ \\
\hline $\begin{array}{l}\text { 9. Increasing } \\
\text { Image }\end{array}$ & $\begin{array}{l}\text { 56. Increasing service quality } \\
\text { 57. Offering substantial discounts } \\
\text { 58. Complying with regulations } \\
\text { 59. Using branded systems }\end{array}$ \\
\hline $\begin{array}{l}\text { 10. Increasing } \\
\text { Quality }\end{array}$ & $\begin{array}{l}\text { 60. Supplier/vendor management } \\
\text { 61. Work result } \\
\text { 62. Services } \\
\text { 63. Products }\end{array}$ \\
\hline $\begin{array}{l}11 . \text { Increasing } \\
\text { Internal Services }\end{array}$ & $\begin{array}{l}\text { 64. Shared services } \\
\text { 65.Matching employee's right and } \\
\text { responsibility } \\
\text { 66. Employee services } \\
\text { 67. Proper schedule and training material }\end{array}$ \\
\hline
\end{tabular}

\begin{tabular}{|c|}
\hline $\begin{array}{ll}\text { 12. Increasing } & \begin{array}{l}\text { 68. Forming business alliances } \\
\text { Competitive }\end{array} \\
\text { Advantage } & \begin{array}{l}\text { 69.Accelerating the execution of new } \\
\text { business opportunities } \\
\text { 70. Increasing switching cost }\end{array}\end{array}$ \\
\hline $\begin{array}{ll}\text { 13. Avoiding Cost } & \text { 71. Reserved fund } \\
& \text { 72. Maintenance cost } \\
& \text { 73. Lost and delay cost } \\
\end{array}$ \\
\hline 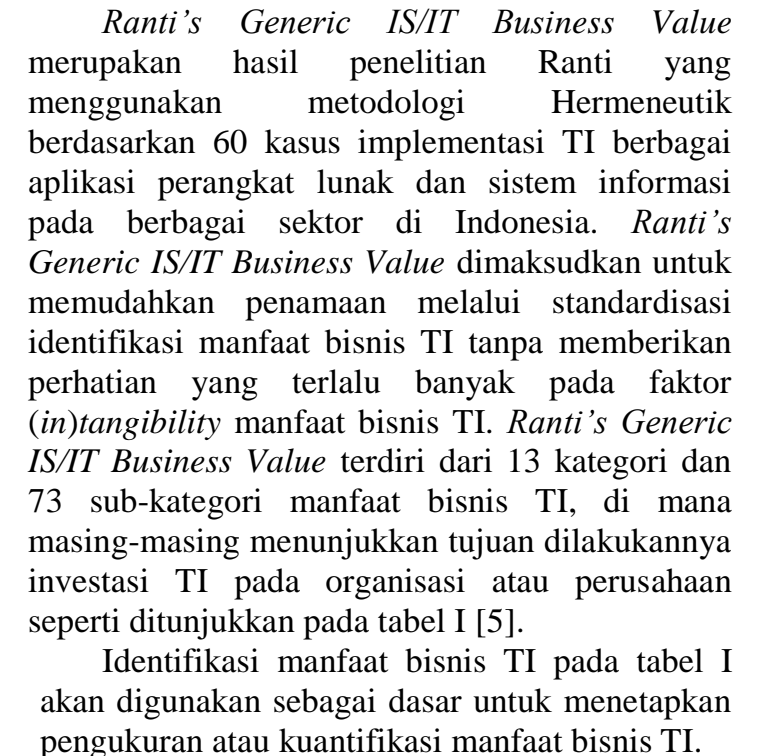 \\
\hline
\end{tabular}

\section{Metodologi}

Penelitian ini menggunakan pendekatan studi kasus berdasarkan tahapan penelitian seperti yang ditunjukkan pada gambar 3. Terdapat tiga tahapan dalam penelitian ini.

Tahap 1. Pengukuran tingkat kematangan manajemen investasi TI. Sejumlah 93 praktek kunci ditanyakan melalui kuesioner ITIM untuk mendapatkan tingkat kematangan manajemen investasi TI saat ini [4]. Tahap 2. Implementasi KKF. Proses manajemen investasi TI seperti yang dikemukakan Over [8] digunakan sebagai dasar implementasi KKF, dan Komite Pengarah TI seperti hasil penelitian Grembergen [7] digunakan sebagai acuan pengembangan organisasi pengelola investasi TI. Tahap 3. Pengukuran kembali tingkat kematangan manajemen investasi TI. Setelah penerapan KKF dan menyediakan fungsi pengelola investasi TI dalam organisasi, maka dilakukan pengukuran ulang untuk mengetahui tingkat kematangan manajemen investasi TI.

\section{Analisis dan Pembahasan}

Hasil pengukuran pada tahap awal ini menunjukkan bahwa terdapat 22 praktek kunci yang dilakukan oleh BUMN tersebut. Menurut kerangka ITIM, tingkat kematangan manajemen investasi TI adalah pada tahap 1, seperti yang 
ditunjukkan pada gambar 4.

Hal ini menunjukkan manajemen investasi TI pada BUMN ini masih bersifat ad hoc, tidak terstruktur, dan tidak dikelola dengan baik. Setiap proyek atau investasi TI dilaksanakan secara terpisah tanpa ada pembelajaran dari pengalaman proyek TI yang telah dilakukan sebelumnya.

Berdasarkan hasil ini maka ada kebutuhan untuk memperbaiki proses manajemen investasi TI dengan menerapkan KKF dan memerbaiki organisasi pengelola investasi TI untuk meningkatkan tingkat kematangan manajemen investasi TI.

Strategi Implementasi KKF pada Proses Manajemen Investasi TI, gambar 5 menunjukkan implementasi KKF pada tahapan manajemen investasi TI. Penerapan KKF pada tahap praseleksi (KKF-01: Identifikasi) bertujuan untuk memudahkan proses identifikasi investasi TI yang sesuai dengan kebutuhan bisnis. Tujuan dari tahap praseleksi adalah untuk mendapatkan investment/business case yang berisi rincian biaya, manfaat, dan potensi risiko investasi TI yang diusulkan. Ranti's Generic IS/IT Business Value dapat digunakan untuk mengidentifikasi manfaat bisnis TI yang selaras dengan strategi bisnis.

Pada tahap Seleksi (KKF-02: Seleksi), KKF digunakan sebagai pedoman standar untuk mengevaluasi dan menyetujui portofolio investasi TI. Pada tahap pengendalian (KKF-03: Pengendalian), KKF digunakan untuk memastikan bahwa proses investasi TI yang sedang berlangsung dapat dikendalikan. Tahap ini ditandai dengan keputusan dan tindakan untuk melanjutkan, memodifikasi, atau bahkan menghentikan proses investasi TI yang sedang berjalan. Pada tahap Evaluasi (KKF-04: Evaluasi), hasil investasi TI dibandingkan dengan rencana awal. Peran KKF adalah sebagai pedoman standar dalam proses post-audit atas investasi TI yang dilakukan.

Pengorganisasian Pengelola Investasi TI. Berdasarkan kerangka manajemen investasi TI, di samping menerapkan KKF, maka strategi lainnya adalah membentuk Dewan Investasi TI atau Komite Pengarah TI di tingkat strategis seperti yang ditunjukkan pada gambar 6. Komite ini memiliki tanggung jawab untuk menentukan kebijakan yang berkaitan dengan investasi TI dari tahap praseleksi hingga tahap Evaluasi. KKF akan menjadi instrumen standar untuk Komite Pengarah TI dalam melaksanakan kebijakan pada setiap tahap manajemen investasi TI.
Tingkat Kematangan Manajemen Investasi TI Setelah Implementasi KKF dan Komite Pengarah TI. Hasil pengukuran kembali menunjukkan peningkatan dengan terpenuhinya praktek kunci pada BUMN dari 22 ke 65 . Berdasarkan kerangka ITIM, tingkat kematangan manajemen investasi TI adalah pada tingkat 3 seperti yang ditunjukkan gambar 7. Penerapan KKF mampu memenuhi proses penting, yaitu: (a) Menangkap informasi investasi, di mana KKF mampu memberikan informasi yang relevan terkait biaya dan manfaat TI; (b) Menyediakan pengawasan investasi, di mana informasi yang diberikan oleh KKF dapat digunakan sebagai kriteria untuk memantau atau melacak kinerja investasi TI; (c) Memilih investasi, di mana KKF digunakan sebagai kerangka kerja untuk memilih investasi TI secara ketat; (d) Memenuhi kebutuhan bisnis, dimana KKF merepresentasikan kebutuhan bisnis dalam bentuk manfaat bisnis TI; dan (e) Melakukan tinjauan pasca implementasi, di mana KKF digunakan sebagai kerangka untuk membandingkan hasil investasi TI yang diharapkan dengan yang ada saat ini [11].

Sementara itu, keberadaan Dewan Pengarah TI berkontribusi dalam: (a) Melembagakan Komite Pengarah TI, di mana keberadaan Komite Pengarah TI berfungsi untuk memilih, mengendalikan, dan mengevaluasi investasi TI; (b) Menciptakan portofolio investasi TI, di mana Komite Pengarah TI mendefinisikan portofolio investasi TI yang akan dipilih; (c) Mendefinisikan kriteria portofolio investasi TI, di mana Komite Pengarah TI mengembangkan dan memelihara kriteria seleksi portofolio investasi TI yang selaras dengan strategi bisnis perusahaan; dan (d) Mengevaluasi portofolio investasi TI, di mana Komite Pengarah TI mengukur kinerja portofolio investasi TI dan menyesuaikan alokasi sumber daya yang dibutuhkan untuk investasi TI.

Gambar 8 memerlihatkan ringkasan dari keseluruhan proses yang telah dijelaskan sebelumnya dalam rangka meningkatkan kematangan manajemen investasi TI dari tingkat 1 ke tingkat 3. Ada 3 komponen utama yang memainkan peranan penting dalam meningkatkan tingkat kematangan manajemen investasi TI yang ditemukan dalam penelitian ini. Komponen utama tersebut adalah kerangka ITIM untuk mengukur tingkat kematangan, KKF berdasarkan Ranti's Generic IS/IT Business Value yang menjadi pedoman standar dalam setiap tahap investasi TI, serta perbaikan struktur dan fungsi organisasi TI dengan membentuk Komite Pengarah TI pada BUMN. 


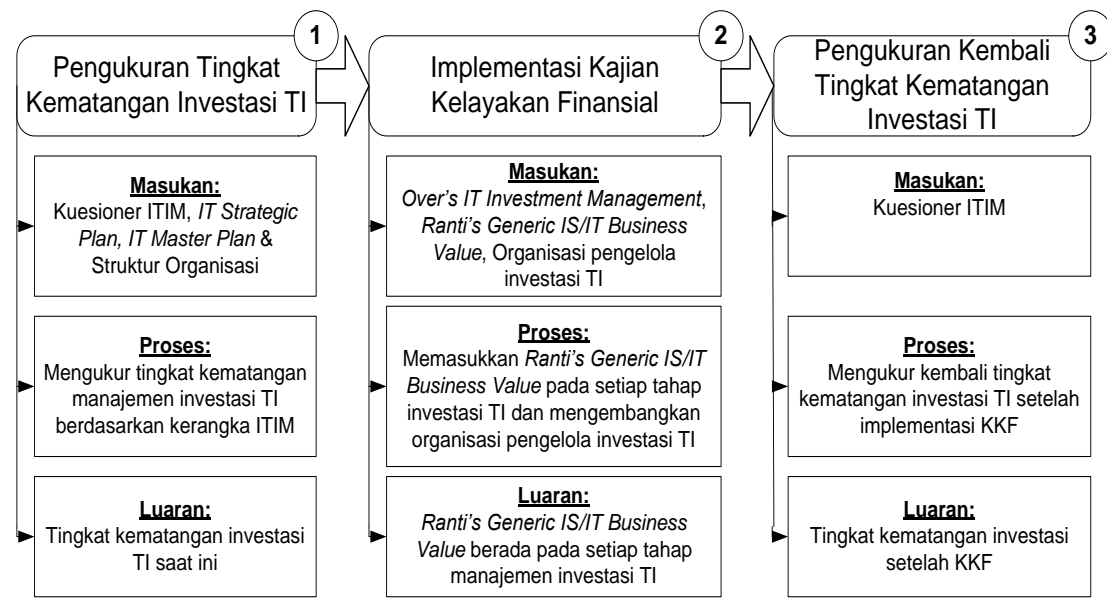

Gambar 3. Tahapan penelitian.

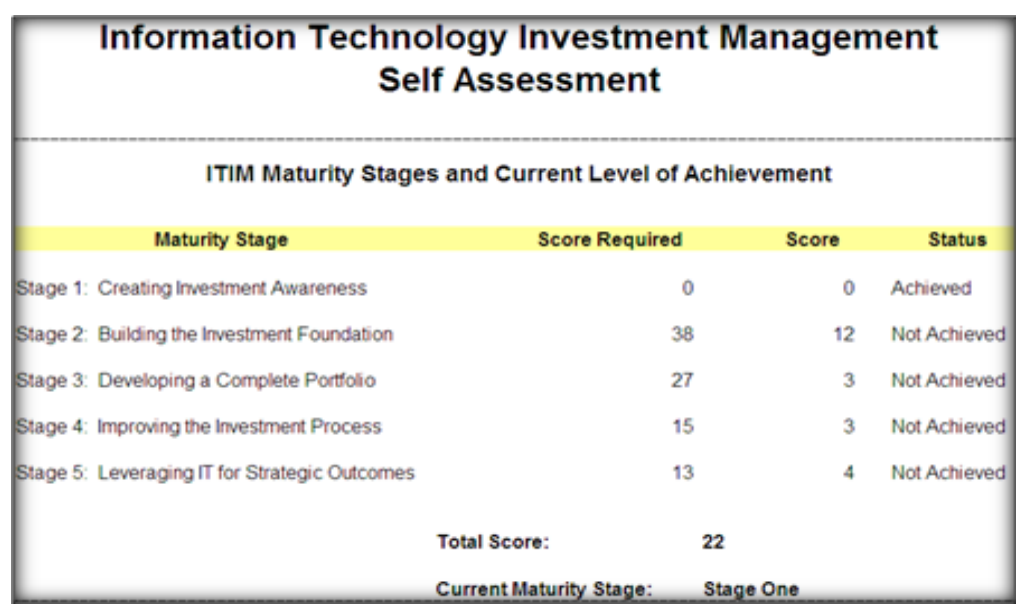

Gambar 4. Tingkat kematangan manajemen investasi TI.

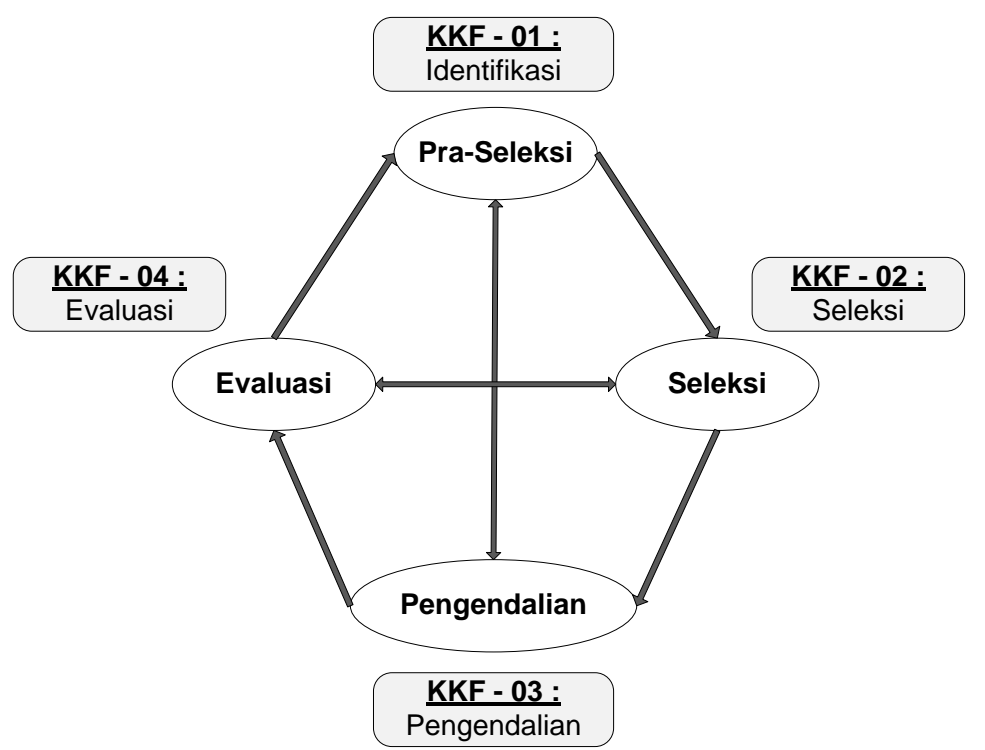

Gambar 5. Implementasi KKF pada manajemen investasi TI. 


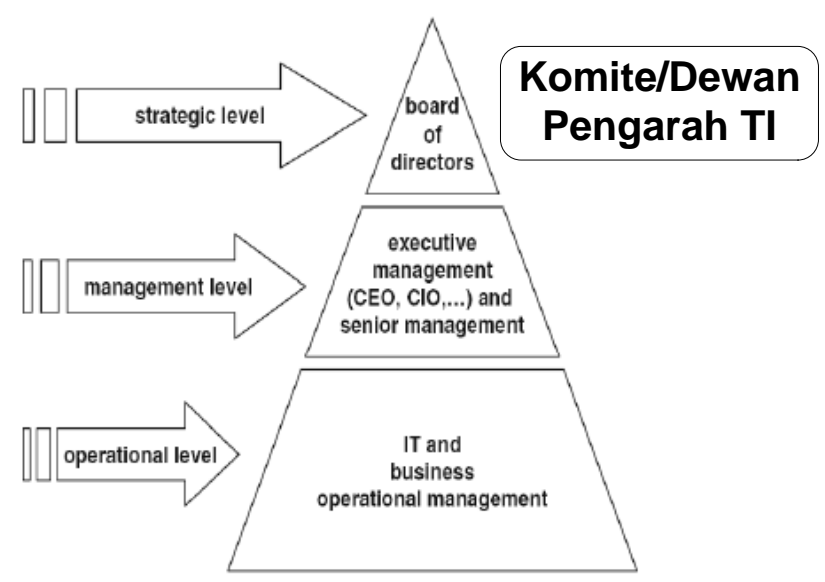

Gambar 6. Fungsi Komite Pengarah TI pada tingkat strategis.

\begin{tabular}{|c|c|c|c|}
\hline \multicolumn{4}{|c|}{$\begin{array}{c}\text { Information Technology Investment Management } \\
\text { Self Assessment }\end{array}$} \\
\hline \multicolumn{4}{|c|}{ ITIM Maturity Stages and Current Level of Achievement } \\
\hline Maturity Stage & Score Required & Score & Status \\
\hline Stage 1: Creating Irvestment Awareness & 0 & 0 & Actiered \\
\hline Slage 2 . Bulaling the Irrvestment Foundation & 38 & 38 & Actieved \\
\hline Stage 3: Developing a Complete Porttolio & 27 & 27 & Actieved \\
\hline Stage 4: Improwing the Irvestment Process & 15 & 0 & Not Achieved \\
\hline tage 5: Leveraging Ir for Strategic Oucomes & 13 & 0 & Nor Achieved \\
\hline \multicolumn{4}{|c|}{ Total Score: $\quad 65$} \\
\hline & laturity Stage: & & \\
\hline
\end{tabular}

Gambar 7. Tingkat kematangan manajemen investasi TI setelah implementasi KKF dan Komite Pengarah TI.

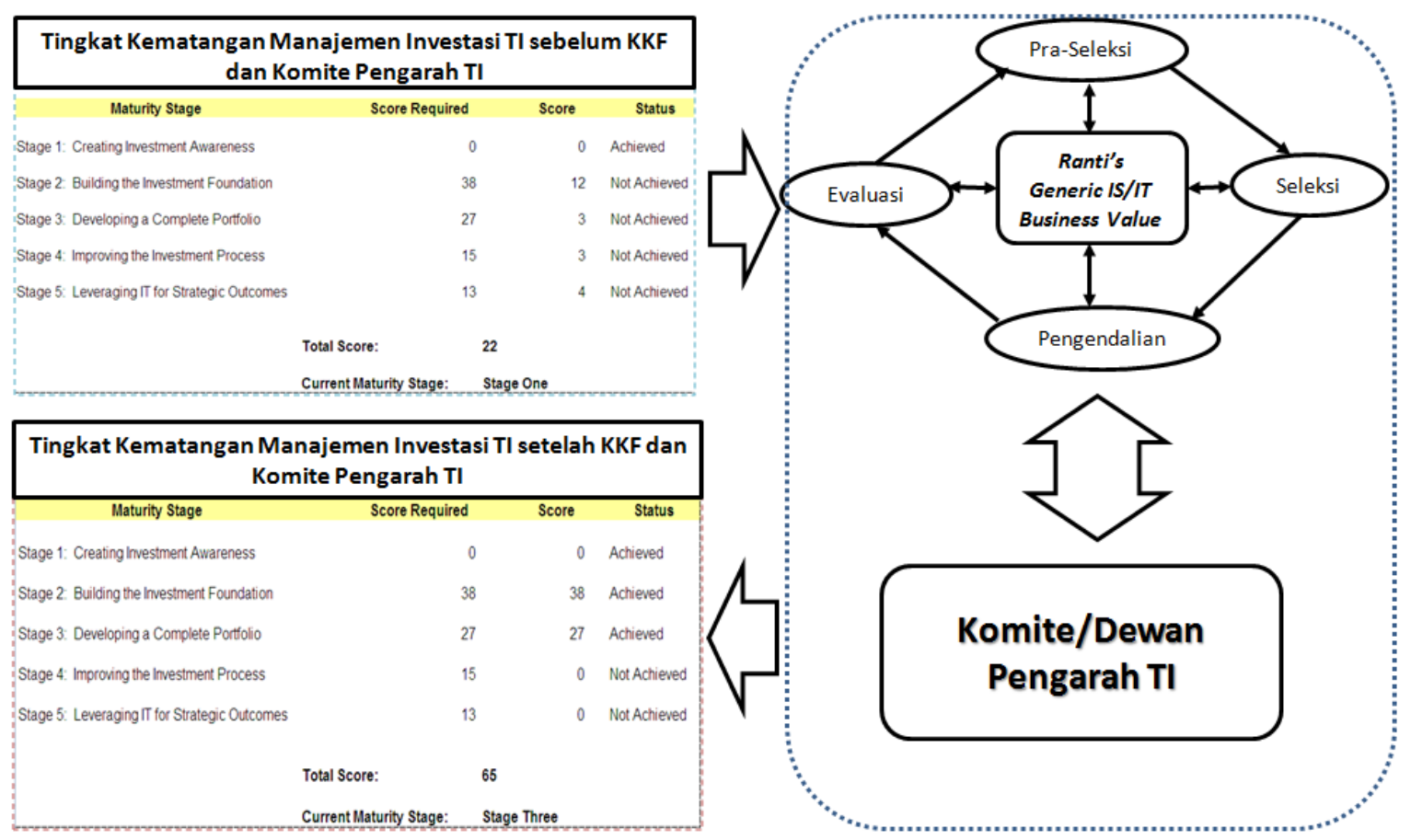

Gambar 8. Proses untuk meningkatkan tingkat kematangan manajemen investasi TI. 


\section{Kesimpulan}

Penerapan pedoman standar seperti KKF berdasarkan Ranti's Generic IS/IT Business Value secara konsisten dan terus menerus dapat meningkatkan tingkat kematangan manajemen investasi TI. Hal yang membedakan KKF yang digunakan dalam penelitian ini dengan KKF "seperti biasanya" adalah pada penggunaan kerangka dan pedoman standar berdasarkan Ranti's Generic IS/IT Business Value. Kerangka ini digunakan secara konsisten pada keseluruhan siklus hidup investasi TI, mulai dari tahap praseleksi hingga tahap evaluasi.

Komponen kunci lain yang juga memainkan peranan penting adalah adanya Komite Pengarah TI atau fungsi serupa lainnya dalam struktur organisasi TI. Komite Pengarah TI ini akan menggunakan KKF berdasarkan Ranti's Generic IS/IT Business Value sebagai kerangka kerja untuk membantu mereka mengelola seluruh proses dalam siklus hidup investasi TI.

Tentu saja kajian lanjutan dalam bentuk kajian empiris dan teoritis perlu dilakukan untuk meningkatkan tingkat kematangan manajemen investasi TI, terutama pemanfaatan Ranti's Generic IS/IT Business Value. Penggunaan kerangka ini dapat terus ditingkatkan, bagi profesional TI, terutama pimpinan perusahaan yang berharap untuk mendapatkan manfaat bisnis atas investasi TI yang telah dilakukan dalam jumlah yang besar.

\section{Referensi}

[1] F. Bergeron, L. Raymond, \& S. Rivard, "Ideal Patterns of Strategic Alignment and Business Performance," Journal of Information \& Management, vol. 41, pp. 1003-1020, 2004.

[2] W.V. Grembergen, S.D. Haes, \& H.V. Brempt, Building the Business Case for
CobiT® and Val IT ${ }^{\mathrm{TM}}$ : Executive Briefing, ISACA, USA, 2009.

[3] ITGI, Control Objectives for Information and related Technology (COBIT 4.1), IT Governance Institute, USA, 2007.

[4] GAO, Information Technology Investment Management: A Framework for Assessing and Improving Process Maturity, United States General Accounting Office, Washington, 2004

[5] B. Ranti, "Identification of Information System/Information Technology Business Value With Hermeneutic Approach: Cases in Indonesia," Dissertation, Faculty of Computer Science, Universitas Indonesia, Indonesia, 2008.

[6] P. Weill \& J.W. Ross, IT Governance: How Top Performers Manage IT Decision Rights for Superior Results, Harvard Business School Press, Boston, 2004.

[7] W.V. Grembergen \& S.D. Haes, Enterprise Governance of Information Technology, Springer, New York, 2009.

[8] D.V. Over, Use of Information Technology Investment Management To Manage State Government Information Technology Investment, IGI Global, pp. 1-22, 2009.

[9] R.S. Pressman, Software Engineering: A Practitioner's Approach, 6th ed., Mc-Graw Hill, 2005.

[10] A. Dennis, B.H. Wixom, \& D. Tegarden, System Analysis and Design with UML: An Object-Oriented Approach, John Wiley \& Sons, New Jersey, 2010.

[1] J. Tambotoh, "The Implementation of Financial Feasibility Study to Increase the IS/IT Investment Management Maturity Level. Case Study: PT. XYZ (Persero)," Thesis, Faculty of Computer Science, Universitas Indonesia, Indonesia, 2010. 